\title{
АНАЛІЗ ДІЯЛЬНОСТІ ПІДПРИЄМСТВ СІЛЬСЬКОГОСПОДАРСЬКОГО МАШИНОБУДУВАННЯ В УМОВАХ ПІСЛЯКРИЗОВОГО ВІДНОВЛЕННЯ
}

\author{
АНАЛИЗ ДЕЯТЕЛЬНОСТИ ПРЕДПРИЯТИЙ \\ СЕЛЬСКОХОЗЯЙСТВЕННОГО МАШИНОСТРОЕНИЯ В УСЛОВИЯХ \\ ПОСТКРИЗИСНОГО ВОССТАНОВЛЕНИЯ
}

\section{ANALYSIS OF AGRICULTURAL MECHANICAL ENGINEERING ENTERPRISES IN POST-CRISIS RECOVERY CONDITIONS}

У статті дослідженосучасний стан вітчизняних підприємств сільськогосподарського машинобудування у динаміці їх розвитку за основними напрямами фінансово-господарської діяльності. Проаналізовано обсяг необхідної сільськогосподарської техніки та обсяг виробленої промислової продукції підприємствами сільськогосподарського машинобудування Украӥни за минулий рік, проведено порівняння виробничих результатів діяльності підприємств сільськогосподарського машинобудування у розрізі різних видів реалізованої продукиіі, визначено питому вагу експорту та імпорту продукиії сільськогосподарського машинобудування в загальних обсягах українського експорту та імпорту на сьогоднішній день. Виокремлено основні проблеми та фактори впливу на розгортання кризових явищ на підприємствах.

Результати проведеного дослідження засвідчують наявність та поступове поглиблення кризових явищ на підприємствах сільськогосподарського машинобудування та, відповідно, необхідність застосування інструментів антикризового управління для їхнього подолання. Доведено, щзо з метою виведення підприємств з кризи необхідно проводити розробку національної програми розвитку сільськогосподарського машинобудування, а також звернути увагу на інвестування иієї галузі із можливістю залучення іноземного капіталу.

Ключові слова: сільське господарство, аграрне підприємство, техніка, сільськогосподарське машинобудування, промисловість.

В статье исследовано текущее состояние отечественных предприятий сельскохозяйственного машиностроения в динамике их развития по основным направлениям финансово-хозяйственной деятельности. Проанализировань объем необходимой сельскохозяйственной техники и объем произведенной промышленной продукиии предприятиями сельскохозяйственного машиностроения Украины за прошльій год, проведено сравнение производственных результатов деятельности предприятий сельскохозяйственного машиностроения в разрезе различных видов реализованной продукиии, определен удельныи вес экспорта и импорта продукиии сельскохозяйственного машиностроения в общем объеме украинского экспорта $и$ импорта на сегодняшний день. Выделены основные проблемы и факторы влияния на развертывание кризисных ситуаций на предприятиях. 
Результать проведенного исследования свидетельствуют о наличии $u$ постепенном углублении кризисньх ситуаций на предприятиях сельскохозяйственного машиностроения $u$, соответственно, необходимость применения инструментов антикризисного управления для их преодоления. Доказано, что с иелью вывода предприятий из кризиса необходимо проводить разработку начиональной программы развития сельскохозяйственного машиностроения, а также обратить внимание на инвестирование этой отрасли свозможностью привлечения иностранного капитала.

Ключевые слова: сельское хозяйство, аграрное предприятие, техника, сельскохозяйственное машиностроение, промышленность.

This paper investigates the current state of the domestic agricultural machine building enterprises in the dynamics of their development $i$ of the main indicators of financial and economic activity. The authors analyses the volume of industrial production agricultural machines and the volume of industrial production enterprises of agricultural engineering Ukraine last year, compared the production performance of the agricultural machine building enterprises in terms of different types of sales, defined the share of exports and imports of agricultural engineering in total Ukrainian exports and imports on present day. Thesis there is determined the main problems and impacts on the deployment of the crisis on enterprises.

Results The survey results confirm the presence and gradual deepening crisis in the agricultural engineering companies and, accordingly, the need for crisis management instruments to overcome them. It is proved that in order to drive business out of the crisis it is necessary to elaborate a national program of agricultural machinery, as well as pay attention to investment in this sector to attract foreign investment. industry.

Keywords: agriculture, agricultural business, engineering, agricultural engineering,

Вступ. Сьогодні розвиток аграрного сектору України має тенденціюдо неефективного використання традиційних методівменеджменту. За сучасних умов, колигосподарській діяльності притаманні не тільки тимчасові труднощі у аграрному секторі економіки, але й стан глибокої непоборної кризи в цілому,звичайні інструменти менеджменту вже не $є$ дієвими. Тому, актуальноюпроблемою наразі $є$ пошук і впровадження у широку практику таких форм іметодів управління, використання яких запобігало б виникненнякризового стану та сприяло б підготовці та реалізації програми оздоровленняпідприємствасільськогосподарського машинобудування.

Сільськогосподарське машинобудування у різних аспектах розглядається в доробках таких вчених, як В. М. Булгаков, Д. Г. Войтюк, Е. А. Зінь, В. В. Ковалевський, Ю. Г. Козак, В. О. Кондратець, В. Н. Кузьмін, Ю. Ф. Лачуга, І. В. Луциків, І.В. Макалюк, А. Ю. Погребняк, О. В. Собкевич, С. М. Рижук та інші. Науковці зазначали, що розвинуте сільськогосподарське машинобудування $\epsilon$ індикатором розвитку АПК будь-якої країни. Висока механізація праці $\epsilon$ запорукою зростання обсягів i якості виробленої сільгосппродукції. У той же час, незабезпеченість галузі необхідною кількістю сільськогосподарської техніки є серйозним бар'єром для розвитку сільського господарства.

Постановка завдання. Метою даної статті $є$ аналіз динаміки розвитку підприємств аграрного сектору України, що спеціалізуються на виробництві сільськогосподарської техніки в умовах післякризового відновлення. 
Методологія. Для досягнення поставленої мети використано загальнонаукові та спеціальніметоди дослідження, такі як: метод синтезу та аналізу, прийоми логічного узагальнення, системнийаналіз, методи порівнянь, узагальнень і аналогій, аналіз статистичних даних та наукових публікацій,табличний i графоаналітичний методи. Теоретичною базою дослідження стали наукові працівітчизняних та зарубіжних учених щодо аналізу діяльності підприємств сільськогосподарського машинобудування.

Результати дослідження.Сільське господарство являє собою одну 3 провідних галузей економіки України, яка на сьогоднішній день збереглазначні конкурентні переваги.У 2015 році частка сільського господарства в структурі ВВП країни вперше у вітчизняній історії досягла рівня вище $10 \%$, а саме - $10,43 \%$. Таким чином, агросектор поступово став ключовою статтею, яка наповнюєдержавний бюджет[4].

Варто зазначити, що у 2015 роціУкраїна посіла почесне восьме місце серед десятки головних експортерів сільськогосподарської продукції до країн Євросоюзу. Цього ж року кількість імпортованоїукраїнської сільськогосподарської продукції до країн ЄС склалавагому суму в 3,5 млрд євро. Варто відзначити, що за поточний рік цей показник,на жаль, зменшився майже на $15 \%$.

Що стосується техніки для АПК на вітчизняному ринку, то слід розуміти, що саме останній залишається основним місцем взаємодії інтересів продавців і покупців практично всіх технічних засобів. Серед таких аграрію пропонуються сучасні машини, механізми, обладнання, устаткування, технологічні комплекси і лінії, які безпосередньо застосовуються у сільському господарстві, харчовій і переробній промисловості для вирощування, збору, зберігання та переробки продукції, а також для надання послуг 3 технічного сервісу. Центральними постатями цього ринку залишаються підприємства-виробники матеріально-технічних ресурсів, торгово-посередницькі організації і дилери, сервісні підрозділи, а також інші формування у даній сфері[6].

Позитивна тенденція до збільшення обсягів сільськогосподарського виробництва протягом останніх років зумовилазростання попиту аграріїв на сільськогосподарську техніку вітчизняного виробництва, що, у свою чергу, сталопотужним поштовхом як для розвитку самого ринку техніки в цілому, так і для вітчизняного машинобудування, а також викликало активізацію імпорту необхідної продукції від провідних світових компаній.

Минулорічний показник ємності ринку техніки для сільськогосподарського машинобудуваннястановив близько 8,9 млрд грн, i, враховуючи значний рівень зношеності основних засобів та необхідність масштабного оновлення існуючого на підприємствах матеріально-технічного парку, за умов стабілізації економічної ситуації в країні може в подальшому суттєво збільшитися.

Нижче наведена структура купівлі аграрними підприємствами різних видів техніки й агрегатів за минулий рік (рис. 1). 


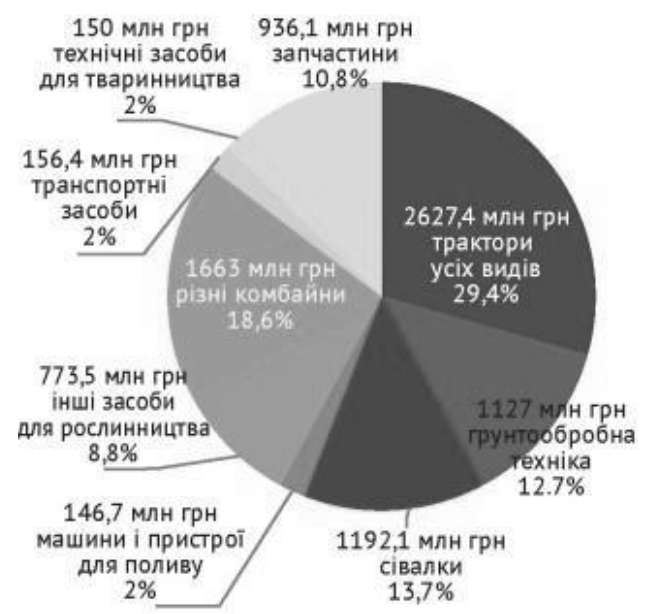

Рис. 1. Обсяг і структура купівлі технічних засобів у 2015 р. Джерело: Побудовано автором на основі [1]

Цікавою $є$ тенденція, що при купівлі нових технічних засобів, аграрії та підприємства навали перевагу у першу чергу - тракторам, потім комбайнам, сівалкам та грунтообробним засобам.

Що стосується обсягу купівлі тракторів, їх було придбано на 2,6 млрд грн, або 29,4\% від сумарної вартості технічних засобів, комбайнів - майже на 1,7 млрд грн $(18,6 \%)$, сівалок - на 1,2 млрд грн $(13,7 \%)$ і грунтообробної техніки - на 1,1 млрд грн (12,7\%)[4].

Варто зазначити, що в цілому Україні вдалося все ж таки зберегти окремі галузі сільськогосподарського машинобудування, які на сьогоднішній день здатні витримувати конкуренцію на ринку за рахунок порівняно нижчої вартості продукції та при цьому гарній якості виробленої продукції.

Слід зазначити, що поточний стан i розвиток галузі сільськогосподарського машинобудування були сформовані остаточно через руйнування налагоджених зв'язків. Наприклад, ще декілька років тому потреби в комплектуючих для виробництва техніки вітчизняних аграріїв на $70 \%$ задовольнялися за рахунокімпорту комплектуючих з Росії. Лише $30 \%$ необхідних деталей вироблялося на території України. У подальшому склалася така ситуація, за якої аграрні підприємства знизили свій попит на сільськогосподарську продукціювітчизняного виробництва через нестачу коштів. Таким чином, обсяги реалізації тракторів скоротилися майже у 8 разівчерез високусобівартістьїхвиробництва і паралельне падінняпопиту на них на внутрішньому ринку[3].

Аналіз ринку сільськогосподарської техніки свідчить, щоза останні роки виробництвотракторівщорічномало тенденцію до скорочення. Якщо у 2011 р. їхбуловиробленомайже 6,8 тис.шт., то вже у 2014 р. лише 4,1 тис. шт., а за 9 місяців 2015 р. - 2,9 тис. шт.[4].

Виробництвоплугіввідвальних за вказанийперіодскоротилосяіз 3,6 до 2 тис. шт., хоча в 2012 р. воносягнуло максимального показника за останні 5 років - 13,1 тис. шт. За 9 місяців 2015 року їхбуло вироблено лише 1,3 тис. шт. 
Аналогічнаситуаціясклаласяізвиробництвомсівалок, яке знизилося в цілому з 4,9 тис.шт. у 2011 р. до 3 тис. шт. в 2014 р. і за 9 місяців 2015 р. становило 2,6 тис. шт[4].

Порівнянокращий

стан справ

ізвиробництвомкосарок, обсягякихнавпакизрісіз 2,3 тис. шт. у 2011 р. до 2,9 тис. шт. у 2014 р. і за 9 місяців 2015 року досяг рівня 2,3 тис. шт. [4].

Така негативнатенденція доскороченнявиробництва у 2015 році була зумовленапередусім складною економічноюситуацією в Україні, відчутним погіршеннямфінансовихможливостейаграріїв, що призвело до падіння обсягів придбанняновихтехнічнихзасобів.

Проте, слід звернути увагу на той факт, що за останні роки рівень концентрації землекористування значно підвищився, розвиток агрохолдингових об'єднань набирає обертів, а тому попит на високоякіснітрактори й іншутехніку, передусіміноземноговиробництва буде лишезростати. Можна спрогнозувати певне уповільнення темпів іiі продажу на ринку, яке, вочевидь, буде зумовлене девальвацією національної валюти, але така перспектива буде недовготривалою і в подальшому цей сегмент зберігатимепривабливість для виробниківсільськогосподарськоїтехніки.

Якщо розглянути більш детально дані щодо придбання тракторів на регіональному ринку технічних засобів (за даними аналізу інформації Державної служби статистики України), у 2015 році найбільші закупівлі здійснювалиаграрії Харківської, Кіровоградської, Одеської, Дніпропетровської, Вінницької, Полтавської, Миколаївської, Черкаської, Запорізької i Сумської областей, часткаяких становила $72 \%$ всьогообсягукупівлі у цьомусегменті (рис. 2).

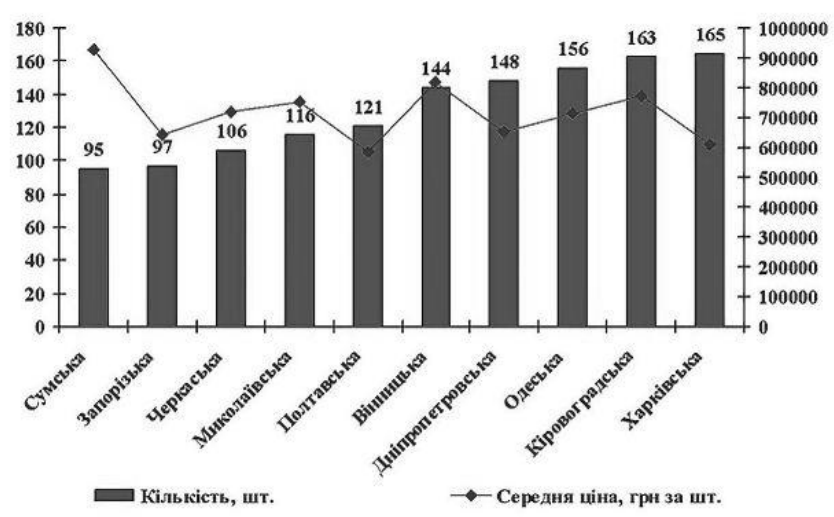

Рис. 2. Топ-рейтинг 10 найбільших регіонів-покупців тракторів усіх видів сільськогосподарськими підприємствами в 2015 р.

Джерело: Побудовано автором на основі [4]

Що стосується рейтингу найбільших покупців сівалок, серед них найбільше виділилися сільськогосподарські підприємства Одеської i Дніпропетровської областей (рис. 3). 


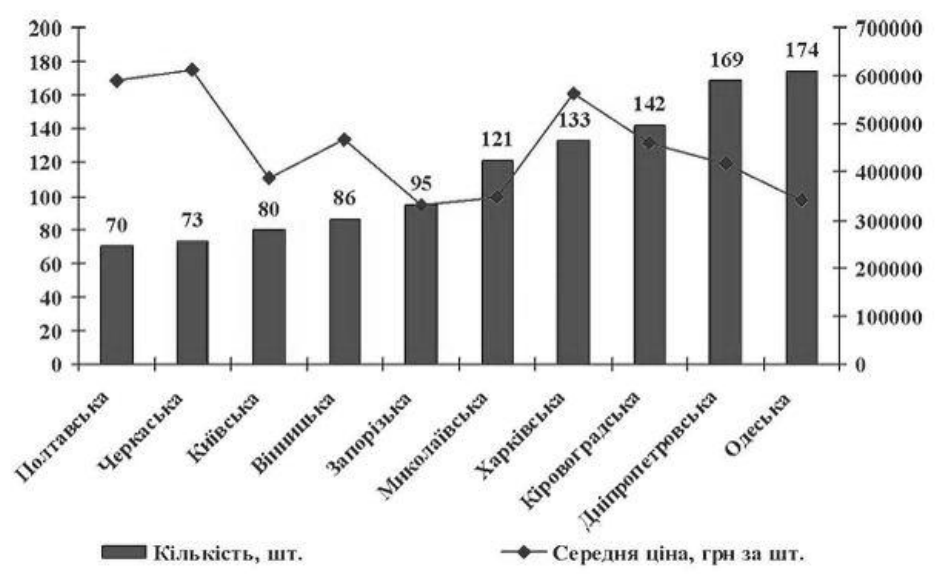

Рис. 3. Топ-рейтинг 10 найбільших регіонів-покупців сівалок усіх видів сільськогосподарськими підприємствами в 2015 р.

Джерело: Побудовано автором на основі [4]

Найбільша кількість зернозбиральних комбайнів була придбана аграрними підприємствами Кіровоградської і Харківської областей (рис. 4).

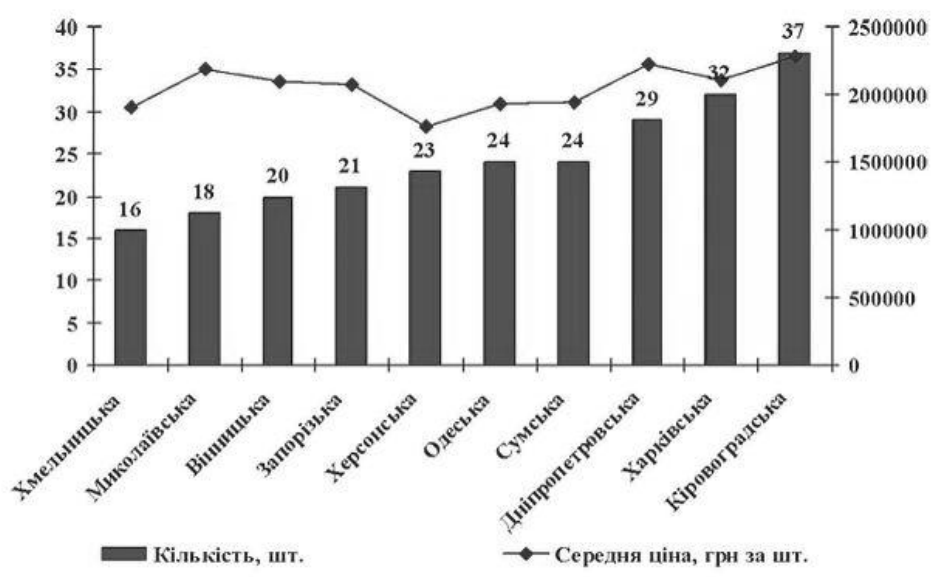

Рис. 4. Топ-рейтинг 10 найбільших регіонів-покупців зернозбиральних комбайнів усіх видів сільськогосподарськими підприємствами в 2015 p. Джерело: Побудовано автором на основі [4]

Отже, сьогоднішня ситуація, що склаласяна вітчизняному ринку техніки для аграрного сектору, з одного боку, була зумовлена поступовим збільшенням попиту на нову економічно вигідну та продуктивну техніку через сприятливі врожаї, що, у свою чергу, дозволило аграріямсуттєвооновитизастарілий машинно-тракторний парк, а з іншого, це було очікуваним результатомсуттєвогопідвищеннявартості техніки через девальваціюгривні і веденнямнових митних правил.

Необхідними заходами для підтримки вітчизняного ринку виробників сільськогосподарської техніки мають стати цілеспрямовані дії держави щодо розробки плану стимулювання аграріїв до повного оновлення технічного парку (наприклад, через механізм залучення пільгового кредитування, розвиток лізингу і компенсації витрат), до комплексної механізації й автоматизації складних технологічних процесів, а також важливим має стати процес контролю за відновленням і збереженням родючості грунту в 
сільському господарстві як на рівні держави, так і на рівні самих аграріїв (через запровадження кращих розробок як вітчизняного машинобудування, так і іноземних виробників аналогічної продукції)[2].

Сучасна потреба аграріїв у спеціальній техніці оцінюється в 7-10 млрд грн. щорічно, в той час як підприємства сільськогосподарського машинобудування мають можливість випускати техніку і запчастини лише на 6,5-7,5 млрдгрн. Обсяги виробництва сільськогосподарської техніки перш за все визначаються платоспроможністю аграріїв, а також обсягами і видами ïx державної підтримки. Відповідно до затвердженої держпрограми виробництва техніки і обладнання для АПКв 2016 р. планується випустити продукції на 2,75 млрдгрн., що на 12\% перевищує обсяги 2015 року[3].

На нашу думку, основні проблеми розвитку сучасного сільськогосподарського машинобудування напряму залежать від їх специфіки - всі вонидосить тісно взаємопов'язані з нестабільним розвитком самого сектору вітчизняного АПК. Таким чином, сільськогосподарське машинобудування має пристосовуватися не тільки до інтересів і потреб аграріїв, а ще і до розроблених державних планів розвитку АПК в цілому[1].

Варто звернути увагу, що існуючі потужності діючих сільськогосподарських підприємств в Україні мають все необхідне, щобповністю відновити виробництво техніки на належному рівні, але така ситуація буде можливою лише за рахунок значних інвестицій для переведення галузі на нові технології.

Наприклад, Кіровоградський завод може забезпечити потреби країни в посівній техніці, тоді як він завантажений лише на 10\%. На деяких підприємствах агропромислової галузі вже впроваджується в роботу виробництво нових видів продукції. Так, Калинівський завод (Вінницька область) за підтримки сільськогосподарських підприємств Німеччини почав випуск нових сівалок. Потужності цього підприємства дають можливість виробляти 3 тис. сівалок на рік (100\% існуючої потреби для вітчизняного АПК). Собівартість виробництва однієї сівалки становить 13,5 тис. доларів (зарубіжні аналоги набагато дорожче - до 20 тис. доларів)[2].

Брянський завод раніше спеціалізувався на виробництві запчастин для російських зернозбиральних комбайнів «Нива». Необхідну продукцію він зможе виробляти і для власних комбайнових підприємств. У радянські часи на полях України працювало близько 112-115 тис. комбайнів, тепер - близько 60 тис. Щорічно комбайновий парк поповнювався на 10 тис. машин російського виробництва. За новою розробленою державною програмою виробництво комбайнів складає 5-6 тис. на рік. Для цього економіка країни має значний потенціал, оскільки традиційно 50\% комплектуючих для Росії проектувалося i виготовлялося саме в Україні. За розрахунками конструкторів собівартість одного комбайна становить 100-110 тис. доларів (ціна одного комбайна «Джон Дір» - 260 тис. доларів). Перші маркетингові зразки показали, що втрати врожаю при роботі цього комбайна становлять лише $1,5 \%$ [4]. 
Варто також зазначити, що ведуться роботи з розробки нового виду комбайнів. У Рівному спільно з датською фірмою створено СП з виробництва комбайнів. Ведуться переговори з США щодо створення підприємств 3 виробництва зернових, кукурудзозбиральних комбайнів, машин для збирання соняшника. Розглядається пропозиція Білорусії про участь України в спільному виробництві зернових комбайнів. Розробляється спільний 3 Польщею проект виробництва зернозбирального комбайна «Бізон» на заводі ім. Малишева (Харків). Запасні частини частково будуть привозитись 3 Польщі, а частково вироблятимуться на заводах України. Можливі поставки продукції в країни СНД. Вартість комбайна може бути в 2-3 рази нижче американської ціни[6].

Львівський завод з виробництва машин для внесення пестицидів i рідких добрив свого часу був унікальним серед країн СНД. Він виробляв близько 20 видів відповідних апаратів. Його потужності розраховані на випуск 60 тис. одиниць продукції. В даний час він виробляє не більше 10 тис. шт., 1/3 яких залишається в Україні, а решта експортується в Росію, Словенію, Угорщину, Фінляндію, Казахстан. Тут налагоджується виробництво нової техніки, перш за все жаток[6].

Отже, процес виведення 3 кризи підприємств АПК $\epsilon$ абсолютно реальним, але потребує розробки адаптованої національної програми розвитку сільськогосподарського машинобудування, яка передбачатиме виробництво технологічних комплексів машин та обладнання для сільського господарства, харчової та переробної промисловості, доведення виробництва нових видів кінцевої продукції та деталей до рівня забезпечення внутрішніх потреб у них щонайменше на $70 \%$.

Найбільш перспективною можливістю для розвитку підприємств сільськогосподарського машинобудування може стати програма інвестування галузі із залученням іноземного капіталу. На нашу думку, політика розвитку сегменту аграрного машинобудування має бути побудована в напрямку досягнення найбільшої самодостатності виробництва максимальної кількості необхідних комплектуючих на території України.

Таким чином, на сьогоднішній день підприємства сільськогосподарського машинобудування мають активно орієнтуватися на використання передового технічного досвіду зарубіжних країн, перепрофілювати виробництво для випуску нових моделей сільськогосподарської техніки та комплектуючих до них, а також розширювати перелік випущених запасних частин і комплектуючих.

Висновки.Незважаючи на глибоку системну кризу національного господарства, галузь сільськогосподарського машинобудування в Україні поступово починає виходити 3 періоду тривалого застою. Про це говорять факти, представлені в періодиці, відбувається поступове зростання потреби аграріїв як у сільськогосподарській техніці, так і в супутніх послугах $\mathrm{i}$ ремонтах. На жаль, вітчизняна промисловість поки що не в силах задовольнити в повному обсязі вимоги сільгоспвиробників. 
Наукова новизна даного дослідження полягає у виявленні основних тенденцій появи кризових явищ на підприємствах сільськогосподарського машинобудування та ключових факторів, що їх спричинили.

Результати дослідженнямають теоретичне значення, а також практичну складову, що може бути використано як основа для подальшої розробки відповідних методів та інструментів, а також організаційних процедур щодо виведення підприємства 3 посткризового стану, при цьому не зазнаючи суттєвих витрат.

У перспективних подальших наукових розробках даний напрям може бути використаний для прогнозування основних показників фінансовогосподарської діяльності підприємств сільськогосподарського машинобудування та удосконалення інструментарію для виведення підприємства аграрного сектору з посткризового стану.

\section{Література:}

1. Коротаєва Ю. Перспективи та проблеми машинобудування / Ю. Коротаєва // Соціально-економічні проблеми і держава. - 2012. - Вип. 1 (6). - С. 82 - 90.

2. Науково-методичне забезпечення діяльності промислових підприємств в умовах нестабільного середовища: Монографія / В.В. Дергачова, Л.С. Довгань, Н.О. Сімченко [та ін.]. —К. : НТУУ «КПІ», —2011. — 380 с.

3. Макалюк I. В. Аналіз величини, структури та динаміки трансакційних витрат на машинобудівному підприємстві / I. В. Макалюк // Сучасні проблеми економіки i підприємництво: збірник наукових праць. - Випуск 11. - Київ : ІВЦ Видавництво «Політехніка», 2013. - С. 276-282.

4. Офіційний сайт Державноїслужби статистики України. [Електронний ресурс]. Режим доступу www.ukrstat.gov.ua

5. Кавтиш О.П. Аналіз динаміки кризових явищ на підприємствах машинобудування / О.П. Кавтиш, А.Ю. Погребняк // Економічний вісник НТУУ "КПІ". 2016. - Вип. 13. - С. 180-187

6. Товажнянський В. Л. Формування антикризового механізму стабілізації та стійкого розвитку машинобудівних підприємств : дис. канд. ек. наук : 08.00 .04 / В. Л. Товажнянський. - Харків, 2011. - 296 с. 